\title{
RUSSIA: ASIA OR EUROPE? \\ REFLECTIONS ON THE AWARENESS \\ OF THE POLISH INTELLIGENTSIA IN THE 19TH CENTURY AS AN IDEOLOGICAL CONTEXT OF NORWID'S WORK
}

Already from a geographical perspective, Russia's location is ambiguous and raises doubts about its belonging in the European continent. However, Europe is not only a geographical name to describe a part of Earth, but also a cultural and civilisational entity. In this respect, Russia's membership in Europe was even more controversial. This problem was noticed by historians studying the history of Europe. Norman Davies noticed: "For more than 500 years, a fundamental difficulty in trying to define Europe has been the lack of an answer to the question whether or not Russia should be included."1 Gerard Delanty stated that in Western Europe, Russia was considered to be "the extension of Asia.", The problem of Russia's Europeanness was even more present in Polish $19^{\text {th }}$ century discourse, in particular considering relations with Russia were quite complicated at the time, which made the issue even more important and topical. The problem of the Europeanness of Russia was pointed out by the Polish poet and geographer Wincenty Pol in one of his works entitled Historyczny obszar Polski:

$[\ldots]$ in this political chaos, Europe cannot determine: where are its eastern borders? Does Russia belong to Europe? Is Europe supposed to see in it only the front guard of Asia? Europe does not know whether it should emancipate itself from the Asian influence of Russia, or to civilise

${ }^{1}$ N. DAVIES, Europa - rozprawa historyka z historia, Polish trans. E. Tabakowska, Kraków 2010, p. 35.

${ }^{2}$ G. Delanty, Odkrywanie Europy. Idea, tożsamość, rzeczywistość, Polish trans. R. Włodek, Warszawa-Kraków 1999, p. 67. 
Russia in order for it to become European? It does not know whether it should recognise the Russian tsar as an ally or a master? Is it a European power or an Asian invader??

When thinking about the issue of the European or Asian character of Russia in context of the awareness of $19^{\text {th }}$ century Polish society, several different aspects of this problem must be taken into account. On one hand, this issue has been raised in scientific discussions about the nationality of Russians. On the other hand, there was also a popular notion of Russians' belonging to a foreign culture, not scientifically motivated, but rather resulting from the conviction about the cultural inferiority of Russians, recognising them as barbarians.

To start with, it is worthwhile consider for a moment the geographical aspect by looking at the eastern border of Europe. The geographical aspect should not be underestimated because, as Wincenty Pol argued, it was also used in "practical politics." Analysing $19^{\text {th }}$ century geography school textbooks, encyclopaedias or maps, one can see that the eastern border of Europe had already been at that time most often marked out along the Ural Mountains, which would mean that at least in part Russia belonged to Europe. However, this was not the rule. Ludwik Pietrusiński noticed in his book Podróże, przejażḋki i przechadzki po Europie that "geographers still have been arguing about Europe's border with Asia." 5 The concept of the border along the Urals was opposed, inter alia, by Wincenty Pol. He believed that the shift of the European border to the Urals (which resulted in the birth of the concept of "European Russia") was the result of a theory developed by German geographers. According to the Polish poet and geographer, however, the facts contradicted these theories and led to completely different conclusions:

3. That Europe's border to the east does not go along the Urals and the Caucasus, but ends up behind the waters of the Daugava and the Dnieper rivers.

4. That the Volga area belongs to closed central Asia, which is not connected by its waters to the open seas of the globe - and thus even less so Europe's borders cannot be marked out along the Urals and the Caucasus, which, after all, nobody counted as European, since everybody knows that the national individualism and Christian civilisation is a feature of European nations. ${ }^{6}$

As seen above, Pol did not stop at purely geographical arguments, but also reached for arguments of cultural and religious nature. In the further part of his

${ }^{3}$ W. Pol, Historyczny obszar Polski, [in:] IDEM, Dzieła proza, Vol. V, Lwów 1878, p. 7.

4 Ibid, p. 8.

5 L. Pietrusiński, Podróże, przejażḋ̇ki i przechadzki po Europie, Vol. I, Warsaw 1843 , p. 385 .

${ }^{6}$ W. PoL, Historyczny obszar, p. 8. 
dissertation, he wrote explicitly about the fact Russia remained foreign to Europe. Here are some arguments put forward by the poet and geographer:

In addition, everything seemingly European is actually Asian in the Moscow society. The Muscovites are throwing themselves into a fight with every European idea like wolves for the prey. No European institution can be accepted or adopted by them. ${ }^{7}$

Asian traditions unknown in Europe - the traditions of Attila, Tamerlan, Batu Khan are the only historical tradition in Moscow, which has taken the nahaj from Nogai, the horse from the Kalmyks, sea from Chude, perversion from Byzantium, the corporal's stick and diplomacy from Germany, and abacus calculation from the Chinese, which skill turned the entire Moscow people into the merchants of land caravans $[\ldots]^{8}$

All European nations, from Spain to Poland, lived during the Christian era a common life unified by the Church, light, customs and Christian civilisation, inventions and progressive ideas of the century. Only Moscow brought nothing into this repository; it did not give Europe a single idea or a single great man who would work for the benefit of humanity [...].

However, despite being a geographer, Pol clearly had an in-depth look at the issue of Russia's Europeanness. In the literary works of other authors, discussions about the location of the eastern border were less frequent and the Urals, as textbooks claimed, were most often considered to be the border of Europe.

The question of the European or Asian membership of Russia was even more complicated when arguments about the origin of Russians were taken into account. It has long been customary to consider Russians as Slavs. At the beginning of the $19^{\text {th }}$ century, the concept of Pan-Slavism, i.e. the political unification of all Slavs under the Russian sceptre (since Russia was considered to be the strongest Slavic country at the time, the only ones enjoying full freedom) was quite popular. In Poland, this proposal did not arouse particular enthusiasm precisely because of the dominant role of Russia; but it also had its supporters here, including Count Henryk Rzewuski and Adam Gurowski. It is also worth mentioning Henryk Kamieński, the author of Rosja i Europa (a work also known to Cyprian Norwid). ${ }^{10}$ Although he did not support the actions and arguments of the aforementioned authors, he claimed that Poland should ally itself with Russia.

${ }^{7}$ Ibid., p. 20.

8 Ibid., p. 21.

${ }^{9}$ Ibid.

10 Norwid mentioned the book Rosja i Europa in a letter to Józef Bohdan Zaleski of 16 July 1857. See C.K. NorwID, Do Józefa Bohdana Zaleskiego, [in:] IDEM, Pisma wszystkie, collected, compiled, introduced and critically annotated by Juliusz Wiktor Gomulicki, Vols. I-XI (Warszawa: PIW, 1971-1976), here Vol. VIII, Warszawa 1971, p. 310. 
However, he put forward other principles of this alliance. Regardless of this, it is worth looking at Kamieński's views on the Russian question. He emphasised the problems that resulted from misunderstanding Russia. In his opinion, Russia was a "puzzle for the whole Europe." 11 According to his definition, Russia "is a country unlike any other, everything becomes something different than it would be anywhere else." ${ }^{12}$ On a different occasion, he stated that neither Russia nor Muscovites can be judged "on a European scale" because "we find something completely different in the state and in the nation." 13 Thus, according to Kamieński, Russia was something separate from Europe; it constituted a separate world. Only Poland, doomed to be its neighbour, was able to mediate in its contacts with Europe making it easier for Europe to understand Russia. However, this concept also met with fierce criticism. In her anonymous dissertation Panslawizm i Polska, Dionizja Poniatowska called Kamieński's "Panslawic system" "ridiculous." 14 In turn, Cyprian Norwid polemicised with Poniatowska's dissertation. ${ }^{15}$

Therefore, Polish creators most often saw the idea of Pan-Slavism as a threat. However, the question of the Slavic nature of Russia has already raised some reservations. In the 1860 s, voices appeared in the discussion about the non-Slavic origin of the Russians who were now accused of only impersonating Slavs. Instead, they were attributed Tartar (and thus Asian) roots. Franciszek Henryk Duchiński is considered the originator of this theory, as he tried to scientifically prove the non-Slavic origin of the Russians. He devoted extensive dissertations to this issue $^{16}$ and gave lectures at the Cercle des Sociétés Savantes. In them he proved that the Russians did not belong to the Slavs either by spirit, language, origin, or character. He strongly emphasised their Mongolian, Finnish and Uralic roots. He wrote in his manifesto Do Rzadu Narodowego powstańczego:

The Muscovites have been foreign to the Slavs and all Indo-European peoples, due to their origins, and due to the nature of their civilisation - and, last but not least, due to historical relations; because the Muscovites are more closely connected with the Turks of Middle Asia, of whom they are an inseparable part, by blood and by origin and by nature of these

${ }^{11}$ H. KAMIEŃSKI, Rosja i Europa: Polska, Paris 1857, p. XLV.

12 Ibid., p. XLV.

13 Ibid., p. 4.

14 [D. PoniatowsKa], Panslawizm i Polska, Poznań 1857, p. 20.

15 C. K. Norwid, O broszurze „,Polska i panslawizm,” PWsz, VII, 187-189.

${ }^{16}$ See F.H. DuchiŃski, Galeria obrazów polskich. Oddział 1, Różnice ludów indoeuropejskich a turańskich pod względem fizjonomii i odzieży, Paris 1863; Pisma Franciszka Duchińskiego, Vols. I-III, Rappersvil 1901-1904. 
civilisations, rather than with their closest neighbours - the Slavs upon the Daugava and the Dnieper rivers. ${ }^{17}$

He also referred to the arguments of geographical nature, stating this time "by the very construction of the earth the Lord united Moscow with the deepest Asia." ${ }^{18}$ He also clearly distinguished between the Russians, whom he postulated to call Muscovites, and the Ruthenians inhabiting the lands on the Dnieper River and Transnistria. In his works, the historian also warned against the historical policy pursued by Russia. He believed that by impersonating the Slavs, the Muscovites wanted to claim their right to rule the other Slavic peoples.

The concept of Duchiński was invoked by Ferdynand Władysław Czaplicki, the author of Czarna ksiega, who referred to the concept when using the terms "Moscow, Muscovite" instead of "Russia, Russian." Similar views were also presented by a Galician political activist, Fr Wojciech Michna, who in his work entitled, Pogląd na wschodnią Europę i Azję i wyjaśnienie stosunków, jakie miała Moskwa z ludami sławiańskiemi od pierwocia bytu do czasów naszych, clearly distinguished the concepts of Russia and Moscow from Ruthenia. According to him, Moscow had a Finnish, and therefore Asian, pedigree. The author used arguments referring to the origin of Russians (he derived them from Finnish and Uralic peoples), nomenclature (the name Moscow was supposed to be derived from Finnish), faith (he pointed to strong connections with "Mohammedanism"), language (the native language was supposed to be derived from Finnish, the language known as Russian, in turn, was created as a result of contacts with Slavs). The views he presented in his dissertation are well summarised in the following passage:

Russia is in one part Christian and in three parts Mongol, it has the European clothing and faith and the Asian spirit! The Slavs have European life, and in Russia it is Asian life. The Slavs followed Christ, and Russia went askew and is a foreigner to the Slavic civilisation as a foreign Finnish tribe, as a foreign Uralic spirit. ${ }^{20}$

Ernest Buława (actually Władysław Tarnowski) also mentioned the Russian impersonation of Slavism. In the introduction to a volume of his poetry (published in 1865) he wrote about Tsar Nicholas I that he is "a tsar of not a Slavic,

17 IDEM, Do Rządu Narodowego powstańczego, ibid., Vol. III, p. 287.

18 Pisma Franciszka Duchińskiego, Vol. II, p. 10.

19 F.W. Czaplicki, Czarna Księga: 1863-1868, Kraków 1869, p. 2.

${ }^{20}$ W. Michna, Poglad na wschodnia Europe i Azją i wyjaśnienie stosunków, jakie miała Moskwa z ludami sławiańskiemi od pierwocia bytu do czasów naszych, Przemyśl 1864, pp. 39-40. 
but a Tartar horde that impersonates Slavism." ${ }^{21}$ Józef Ignacy Kraszewski was also uncertain about this matter, although he finally recognised the issue to be of secondary importance as he wrote in his Rachunki: "Whether the Muscovites are Slavs or Slavicised (like Polonicised) Turans, it does not matter to us, as long as they are not animals." ${ }^{22}$ A clear division between the Slavic and Turanian generations was also shown on the map Granice między narodami Arja-Europejskimi $i$ Turano-Moskiewskimi, dated 1853 in the collections of the National Library. On the Aria-European side there are the cities of Kharkiv, Kiev, Smolensk, Novgorod and Pskov, while on the Turanian side there are the cities of Moscow, Kursk, Kaluga, Vyazma, Belozersk, and most probably also St. Petersburg etc. ${ }^{23}$

The theories about the Asian origin of the Slavs were apparently present in the Polish society's awareness. It is worth noting at this point, however, that a particular intensification of such concepts occurred in the 1860 s, i.e. in the period after the January Uprising which was most probably connected to the increase in aversion of the Russians. Admittedly, there are also numerous previous literary examples where Russians are described as Asians or Mongols, but they had a different character. They did not result from the belief about the actual origin of Russians, but from cultural and civilisational aspects.

However, coming back to Duchiński, whose concepts were also well known to Cyprian Norwid, who listened to the lectures given by the historian at the Cercle des Sociétés Savantes. In his letters, the poet repeatedly polemicised with the theories presented by Duchiński. He distanced himself from the Asian concept of Russia and even criticised it directly. It should be stressed, however, that this was not synonymous with the affirmation of Russia and its politics. The poet saw danger coming from its side, but he was seeking other ways to mitigate it. In his opinion, this could not be achieved by pushing Russia away from Europe and towards Asia. Norwid believed that this could have the opposite effect and lead to an alliance of the Russians with the even more barbaric and numerous Chinese, which would pose a very real threat to Europe. In this respect, he backed Aleksander Wielopolski who was unpopular in the Kingdom of Poland. As he wrote:

Następnie - Wielopolski ma jeszcze tę prawdę, że TRZEBA ROSJI ZOSTAWIĆ NIECO EUROPEJSKIEGO CHARAKTERU: odepchnąć ją od Azji jest to zrobić ją czołem miliona Chińczyków, którzy zaleją świat [...]. Oto, czego patrioci polscy nie chcą wiedzieć - tak iż gdyby się nie zostawiło niejakiej europejskości Rosji, to trzeba by na drugi dzień po zwycięstwie nad Moskalami w ten moment przygotować się do możności wystawienia 300

${ }^{21}$ E. BuŁawa, Krople czary. Poezje, Dresden 1865, p. 9.

22 J.I. Kraszewski, Rachunki: (pt.1-2). z roku 1867 (rok drugi), Poznań 1868, p. 165.

${ }^{23}$ Granice między narodami Aria-Europejskimi i Turano-Moskiewskimi, [s.1.] 1863. 
000 armii i potężnego skarbu - i rozpoczęcia walki z milionami, osłaniając Europę, przedającą armaty, koleje żelazne i pancerne statki każdemu z barbarzyńców, który więcej zapłaci. ${ }^{24}$

Then - Wielopolski is still right in claiming that RUSSIA SHOULD BE ACKNOWLEDGED TO HAVE SOME EUROPEAN CHARACTERISTICS: to push it away from Asia is to make it the forefront of a million of the Chinese who will flood the world [...]. This is what the Polish patriots do not want to know - that if we do not acknowledge some kind of Europeanness to Russia, on the following day after the victory over the Muscovites we will have to prepare ourself for putting up 300,000 armies and a mighty treasure - and for starting a fight with millions, shielding Europe which sells cannons, iron railways and armoured ships to each barbarian who pays more.

According to the poet, difficult relations with Russia should be resolved in a different way than by insulting Russia and recognising it as an Asian and barbaric country. In a letter to Karol Ruprecht he noted that the right solution would be to have a political party in Russia. ${ }^{25}$

As already noted at the beginning, the reason why Russia was often excluded from Europe were civilisational, cultural and religious issues. People were noticing Russia's otherness, its distinct customs, culture, system of values different from the European ones. The sources of Russian civilisation were found in Asia rather than in Europe. This was not only a question of origin, but also of customs and culture which were supposed to be separate from the European ones. Although Russian attempts to adapt to Europe had been noticed, Polish writers often considered these attempts unsuccessful. Some even suggested that Russia had two faces, one European, civilised for the European use, and the other, true - wild, barbaric, very distant from European standards. Polish writers repeatedly claimed that Europe was succumbing to this illusion believing in the Russian civilisation, and did not want to believe the warnings made by Poland which was better acquainted with Russia. According to Józef Ignacy Kraszewski, the civilisation in Russia "has been [...] formal, superficial, empirical; it has been a kind of adopted language that is used to communicate with Europe but not used at home," 26 further he added "the civilisation has merely dyed its skin, but it did not permeate to its blood and juices." 27 According to the writer, the despotism that characterises Russia was supposed to protect Russia from the borders of Europe. In the quoted text there were even words about Russia's alleged hatred towards

\footnotetext{
${ }^{24}$ C.K. Norwid, Philoctet, PWsz VII, 129-130.

25 IDEM, Do Karola Ruprechta, PWsz IX, 107.

26 J.I. KraszewsKi, Rachunki, p. 67.

27 Ibid., p. 68.
} 
everything European. The text also quotes the words attributed by Kraszewski to the Russian philosopher Alexander Herzen:

They drive us out of Europe similarly to God driving Adam from paradise. - But are you also sure that we hold Europe for paradise? And the title European for highly honorable? There has been a big mistake in time. - We are not ashamed to be Asian, and we do not need to attach ourselves to anyone either on the right or the left. We feel good with ourselves, we are part of the world between America and Europe - that is enough for us. ${ }^{28}$

Kraszewski also wrote about the specific attitude of Russians towards Europe in his novel Moskal. A typical Russian or, as the writer calls them, Muscovite "In Europe plays the role of a civilised person, at home he returns to barbarism, liberal in his words, in his actions he is subservient, he quietly sings revolutionary songs, but when called, he joins the row of the Tsar's defenders. ${ }^{29}$ In another place he also wrote: "Although the Muscovites are proud of their country and their civilisation, when going westwards, they unwittingly feel that they are approaching Europe [...]." ${ }^{30}$ Hence, Russia itself was apparently not yet part of Europe.

Russia's problem with defining its own identity was also pointed out by the author of the commentary to the aforementioned map from 1863, who claimed that "the reason for the unconscious attitude of the Slavs towards the Muscovites is to be found in falsifying those for political reasons." ${ }^{31} \mathrm{He}$ also stressed the changeability of Russian policies concerning this issue. As he claimed: "There was a time when the Muscovites came from the Mongols and boasted about it." This was supposed to be the time of Tsar Ivan the Terrible's reign. In the author's opinion, situation changed during the reign of Tsar Peter I, who "wanted to make Muscovites European." ${ }^{33}$ His daughter Elizabeth "wanted to convince him that the Muscivites belonged to Europe, ${ }^{, 34}$ which resulted in repressions imposed on those who had a different opinion on the subject. Catherine II reportedly even issued an ukase claiming that "the Mucsovites are Europeans." Recently, it has become fashionable to derive the Muscovites' origins from the Slavic region. ${ }^{36}$

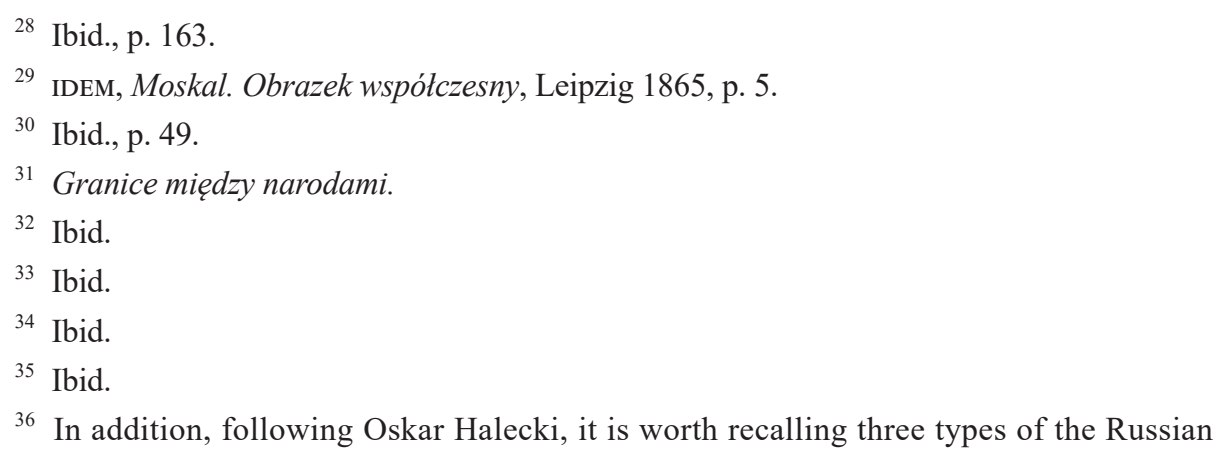


The actions of the Russians to convince Europe about their civilisation and Europeanness did not seem convincing to Polish authors. The nation's own experience was more powerful than the tsar's ukases, and these, more often than not, testified to the barbarism of the Russians rather than to their civilisation. This is why Polish authors often took the opposing side. Their actions were aimed at exposing the lies in Russian messages, throwing off Russia's mask as a civilised country, and making Europe aware of the danger posed by Russia.

In an attempt to create a European-Russian antagonism (following the example of the Polish-Russian antagonism), Polish authors stressed Poland's role as the guardian of Europe, as the protector from the barbaric, Mongolian impulses of Russia. They also tried to show the danger that Europe would be exposed to without this security buffer. In their opinion, Poland was thus a border area, separating what is European from that which is Asian. Russia was pushed into Asia. Such thought patterns were often repeated in the poetry of the times of Polish-Russian fights, but also in journalism.

The threat to Europe from Russia is mentioned in Maurycy Gosławski's poem Do Europy. Europe, passively looking at the fate of Poland, is warned by the lyrical subject about the danger:

\author{
Znieważona i okuta, \\ Drżąc, wyglądasz sensu dnia; \\ Czekaj, nim ci ciężar knuta \\ W dzikiej dłoni Tamerlana \\ Padającej na kolana \\ Przeznaczenie nowe da. ${ }^{37}$ \\ Insulted and in fetters, \\ Trembling, you look for the meaning of the day; \\ Wait till the weight of the whip \\ Held in Tamerlan's wild hand \\ Gives you a new purpose \\ As you are falling to your knees.
}

\begin{abstract}
approach to the issue of its membership: Occcidentalist, Slavophilic and Eurasian. Only the supporters of the first approach considered Russia to be a fully-fledged, albeit somewhat lagging behind, member of the European civilisation. Slavophiles, on the other hand, often emphasised the distinctiveness and superiority of the Slavic region as compared with Western Europe, which they perceived as spoiled. The supporters of the last concept considered Russia as a separate part of the world situated between Asia and Europe. See O. HALECKI, Historia Europy - jej granice i podziały, Polish trans. J. M. Kłoczowski, Lublin 2000, pp. 90-92.

${ }^{37}$ M. GosŁawski, Do Europy, [in:] Zbiór poetów polskich XIX w., compiled and edited by P. Hertz, Book 2, Warszawa 1959, p. 121.
\end{abstract}


"The weight of the whip" and "Tamerlan's wild hand" undoubtedly refer to Russia, which is a threat to Europe. In addition, they suggest the Russian kinship with Asia (Tamerlan was a Mongolian ruler famous for his atrocity, who in the $14^{\text {th }}$ century conquered most of Central Asia; the whip, often associated with Tsarist Russia, was also considered a remnant of the Tartar captivity). The lyrical subject thus refers to the Asian character of the Russians. However, it still did not refer to their origin, but rather to their peculiar mentality completely different from European formed under the influence of the Tartar invaders.

The Asian nature of the Russians was even more strongly emphasised in one of the stanzas of Pieśń strzelców by Władyslaw Ludwik Anczyc from the volume Pieśni zbudzone (1863). The Russians were explicitly classified here as the enemy - "the descendant of Genghis Khan" (the Mongolian ruler at the turn of the $12^{\text {th }}$ and $13^{\text {th }}$ centuries), and Asia has been designated as their proper place:

Do Azji precz, potomku Dżengishana,

Tam naród twój, tam ziemia carskich gal

$[\ldots]$

Do Azji precz tyranie, tam siej mordy, Tam ziemia twa, tam panuj, tam twa śmierć;

Tu Polska jest, tu zginiesz i twe hordy,

Lud naród w pień wymorduj, wysiecz, zgnieć $[\ldots] .{ }^{38}$

To Asia, off you go, Ghenghis Kahn's descendant, There is your people, there is the land of the tsarist galas $[\ldots]$

Out, to Asia, you tyrant, sow your murders there, There is your land, rule there, there is your death; This is Poland, this is where you and your hordes will die, Slaughter, put to the sword, crush the people of the nation [...].

Here, in contrast to the previous work, there is already an indication of the genealogical issue. After all, the Russian enemy is called a descendant of the Mongolian leader. Asianness is not only an acquired trait, but also a part of Russian heritage.

Also in the daily paper "Niepodległość," published during the January Uprising, Poland and Moscow were presented as two hateful powers. Poland was sup-

38 W.L. Anczyc, Pieśń strzelców, [in:] Władysław Ludwik Anczyc: życie i pisma, ed. M. Szyjkowski, Vol. II: Wiersze i poemata, Kraków 1909, p. 88. 
posed to be the "front guard of Europe," ${ }^{39}$ while Moscow "is at the forefront of Asian hordes disinherited from the civilisation." ${ }^{40}$ Moscow was described as a nail in the body of Europe or as a curse hanging over it. ${ }^{41}$ These metaphors indicate a clear alienation of Russia and its rejection from Europe. At the same time, the editors of the newspaper stated that Moscow indeed joined the group of European countries, but it entered it by the rape of Poland. ${ }^{42}$

Norwid's works lack such clear declarations. Even in the works created under the influence of the January Uprising, the poet refrained from creating the image of the Russians by referring to their Asian nature. He remained faithful to the statement that "Rosjanie są tacyż sami Słowianie jak Polacy - tamci z azjatyckimi, ci z europejskimi ludami pomieszani: bo tak być powinno!..." [Russians are the same Slavs as Poles - the former mixed up with Asian peoples, the latter with European ones: because it should be so!.... . $^{43}$

To sum up, it can be observed that under the influence of political events, a tendency emerged to portray Russia as an Asian land and Poland as the bulwark protecting Europe. Norwid did not support this thesis. The poet was well aware of the different nature of Russians. At the same time, however, he was critical of associating Russia with Asianness as it could bring more evil than good. It is worth quoting at this point Mieczysław Inglot's words, which seem to capture the essence of the problem: "Meanwhile, in Norwid's argument, Russia was seen as an arena of the struggle between the European and Asian elements. It was in Europe's interest to Europeanise Russia, and this task was to be undertaken, in the first place, by Poland." ${ }^{44}$

\section{REFERENCES}

„Niepodległość" 1863.

Bulawa E., Krople czary. Poezje, Drezno 1865.

Czaplicki F.W., Czarna księga: 1863-1868, Kraków 1869.

DAviEs N., Europa - rozprawa historyka z historia, trans. E. Tabakowska, Kraków 2010.

Delanty G., Odkrywanie Europy. Idea, tożsamość, rzeczywistość, trans. R. Włodek, WarszawaKraków 1999.

\footnotetext{
39 "Niepodległość" 1863, Issue 4, p. 1.

${ }^{40}$ Ibid.

41 Ibid.

${ }^{42}$ Ibid. Issue 10, p. 1.

${ }^{43}$ C.K. Norwid, Do Bronistawa Zaleskiego, PWsz IX, 321,

${ }^{44}$ M. InGLOT, Norwidowska Europa, [in:] Kategoria Europy w kulturach Stowiańskich, eds.
} T. Dąbek-Wigrowa, A.Z. Makowiecki, Warszawa 1992, p. 65. 
Duchiński F., Galeria obrazów polskich. Oddziat 1, Różnice ludów indoeuropejskich a turańskich pod względem fizjonomii i odzieży, Paryż 1863.

Duchiński F., Pisma..., Vols. I-III, Rappersvil 1901-1904.

Granice między narodami Aria-Europejskimi i Turano-Moskiewskimi, [s.1.] 1863.

HALECKI O., Historia Europy - jej granice i podziały, trans. J.M. Kłoczowski, Lublin 2000.

Inglot M., Norwidowska Europa, [in:] Kategoria Europy w kulturach słowiańskich, ed.

T. Dąbek-Wigrowa, A.Z. Makowiecki, Warszawa 1992.

Kalendarz życia i twórczości Cypriana Norwida, Vols. I-III, eds. Z. Trojanowiczowa, E. Lijewska, Z. Dambek, Poznań 2007.

Kamieński H., Rosja i Europa: Polska, Paryż 1857.

Kraszewski J.I., Moskal. Obrazek współczesny, Lipsk 1865.

KraszewsKi J.I., Rachunki: (pt.1-2). z roku 1867 (rok drugi), Poznań 1868.

Michna W., Pogląd na wschodnia Europę i Azja i wyjaśnienie stosunków, jakie miała Moskwa z ludami sławiańskiemi od pierwocia bytu do czasów naszych, Przemyśl 1864.

Norwid C.K., Pisma wszystkie, compiled, edited and with introduction and critical commentaries by J.W. Gomulicki, Vols. I-XI, Warszawa 1971-1976.

Pietrusiński L., Podróże, przejażḋ̇ki i przechadzki po Europie, Vol. I, Warszawa 1843.

PoL W., Historyczny obszar Polski, [w:] TENŻe, Dzieła proza, Vol. V, Lwów 1878.

Władysław Ludwik Anczyc: życie i pisma, compiled by M. Szyjkowski, Vol. II: Wiersze i poemata; Kraków 1909.

Zbiór poetów polskich XIX w., compiled and edited by P. Hertz, Book 2, Warszawa 1959.

\section{RUSSIA: ASIA OR EUROPE? \\ REFLECTIONS ON THE AWARENESS OF THE POLISH INTELLIGENTSIA IN THE $19^{\mathrm{TH}}$ CENTURY AS AN IDEOLOGICAL CONTEXT \\ OF NORWID'S WORK}

\section{$\mathrm{S} \mathrm{u} \mathrm{m} \mathrm{m} \mathrm{a} \mathrm{r} \mathrm{y}$}

The article discusses the views of the Polish intelligentsia in Cyprian Norwid's lifetime on the issue of Russia's membership in Europe. Among the discussed examples there are particularly frequent attempts to push Russia out of Europe by emphasising its Asian character. The examples of pan-Slavic ideas are less frequent. Against this background, Norwid's views on the question of Russia's Asian nature seem to be exceptionally balanced. The poet noticed that Russia was different, but he believed that isolating it from Europe could be more detrimental than beneficial.

Key words: Russia; Europe; European awareness; pan-Slavism; boundaries of Europe; Slavs.

ANNA M. DwORAK - PhD; e-mail: annadworak17@interia.pl 